\title{
DEFINING THE HARD TISSUE HISTOLOGY OF EUCONODONT ELEMENTS
}

KEMP*, Anne, Dept. of Anatomical Sciences, Univ. Queensland, St. Lucia, Qld., Australia 4072; NICOLL, Robert S., Australian Geological Survey, PO Box 378, Canberra, ACT, Australia, 2601.

The conodont element, composed of hydroxyapatite, is the only mineralised tissue normally present in the conodont animal. This structure is composed of two parts, an upper crown and a lower attachment cone. The crown has generally been recognised as containing two distinct tissue types, an amber colored material, now called hyaline tissue, and a white material, now called albid tissue. However, more detailed investigation of the inter-relationship of the tissues of the crown and attachment cone, in conodont elements with a conodont color alteration index (CAI) value of 1 or 1.5 and which appear to be essentially unaltered, reveals that there are at least two distinct types of hyaline tissue and three types of albid tissue in the crown. In the associated attachment cone there are an additional three tissue types and another hard tissue is present in the interface between the crown and attachment cone.

Recognition of this proliferation of tissue types makes it imperative that, for detailed histological study, the morphologies of conodont hard tissues be clearly documented so that misinterpretation of tissue types and relationships does not obfuscate the functional, taxonomic and phylogenetic study of conodont taxa. The developmental origin and inter-relationship of these tissues is unlike the relationships observed in animals with a vertebrate grade of evolution. 